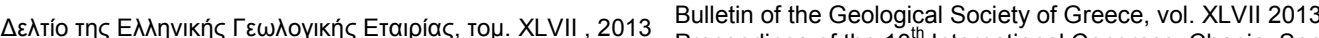
XLVII, 2013 Proceedings of the $13^{\text {th }}$ International Congress, Chania, Sept.

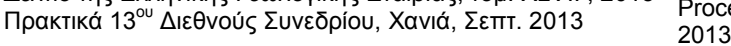

\title{
AMETHYST OCCURRENCES IN TERTIARY VOLCANIC ROCKS OF GREECE: MINERALOGICAL AND GENETIC IMPLICATIONS
}

\section{Voudouris P. ${ }^{1}$, Psimis I. ${ }^{2}$, Mavrogonatos C. ${ }^{1}$, Kanellopoulos C. ${ }^{1}$, Kati M. ${ }^{1}$ and Chlekou E.}

\author{
${ }^{I}$ National and Kapodistrian University of Athens, Faculty of Geology and Geoenvironment, \\ Department of Mineralogy and Petrology,voudouris@geol.uoa.gr,kmavrogon@geol.uoa.gr, \\ ckanellopoulos@gmail.com,kati@geol.uoa.gr, \\ ${ }^{2}$ Maccaferri Hellas Ltd, Athens, giannis.psimis@gmail.com
}

\begin{abstract}
Epithermal-altered volcanic rocks in Greece host gem-quality amethyst veins in association with various silicates, carbonates, oxides, sulfides and halides. Host rocks are Oligocene to recent calc-alkaline to shoshonitic lavas and pyroclastics of intermediate- to acid composition. The amethyst-bearing veins occur in the periphery of porphyry-type and/or high-sulfidation epithermal mineralized centers in northern Greece (e.g. Sapes, Kirki, Kornofolia/Soufli, Lesvos island) and on Milos island in the active Aegean Volcanic Arc. Hydrothermal alteration around the quartz veins includes sericitic, $K$-feldspar (adularia), argillic, propylitic and zeolitic types. Precipitation of amethyst in the northern Greece occurrences, took place during the final stages of the magmatic-hydrothermal activity from near-neutral to alkaline fluids, as indicated by the presence of gangue adularia, calcite, smectite, chlorite, sericite, pyrite, zeolites (laumontite, heulandite, clinoptilolite), analcime and minor amounts of barite, halite, epidote and fluorite in the quartz veins. Amethyst at Milos Island (Chondro Vouno and Kalogries-Vani areas), is accompanied by barite, smectite and lepidocrocite. Colloform-crustiform banding with alternations of amethyst, chalcedony and/or carbonates is a common characteristic of the studied amethyst-bearing veins. Fluid inclusion- and mineralogical data suggest that the studied amethyst were formed at: $174-246{ }^{\circ} \mathrm{C}$ (Sapes area), 100-175 ${ }^{\circ} \mathrm{C}$ (Kirki and Kornofolia areas) and $223-234^{\circ} \mathrm{C}$ (Lesvos island). The amethyst formation requires oxidizing conditions and is probably the result of mixing between meteoric or seawater with upwelling hydrothermal fluids. The involvement of seawater in the studied mineralization is supported by the presence of halite and abundant barite in the veins. Finally, the studied amethyst deposits should be evaluated as potential gemstone sources in Greece.

Key words: amethyst, volcanic rock, hydrothermal alterations, gemstones.
\end{abstract}

\section{Пєрí $\eta \Psi \psi$}

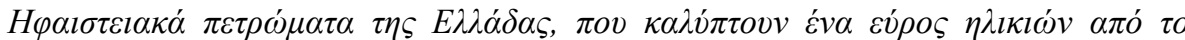

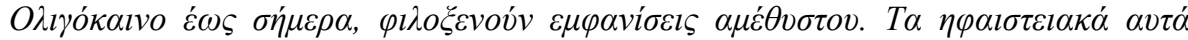

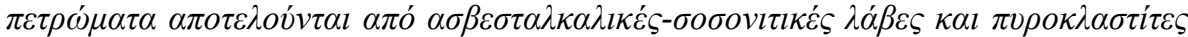

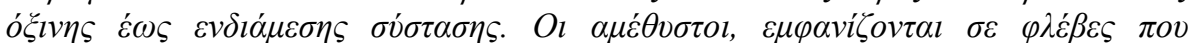




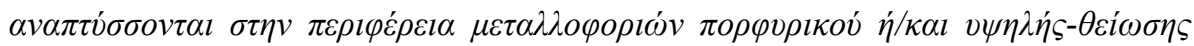

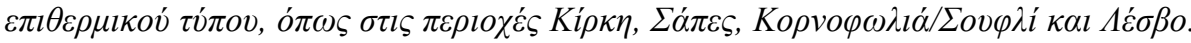

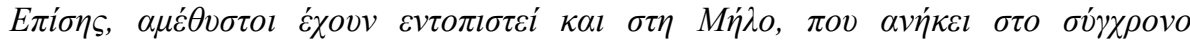

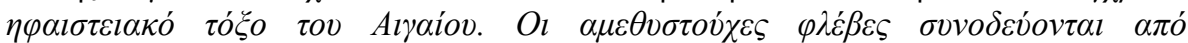

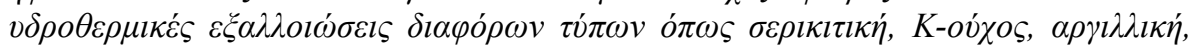

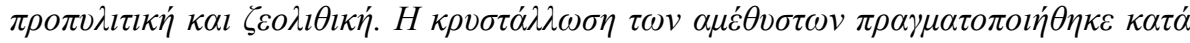

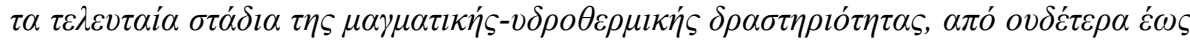

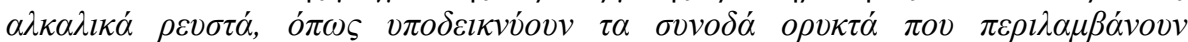

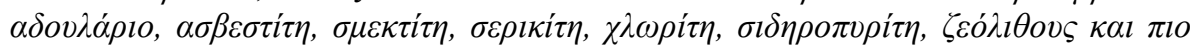

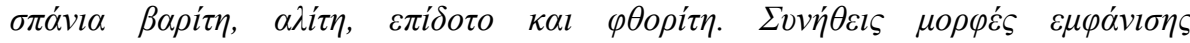

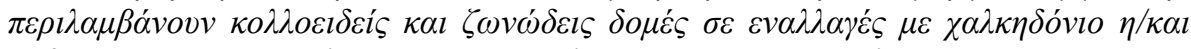

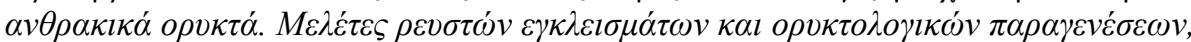

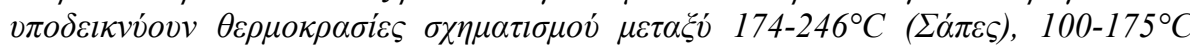

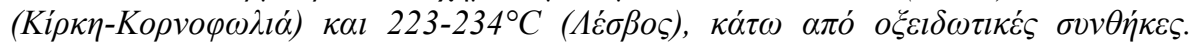

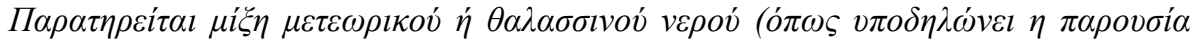

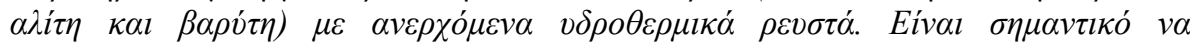

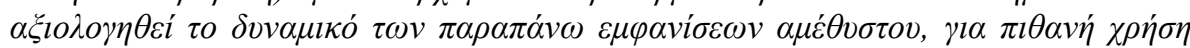

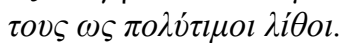

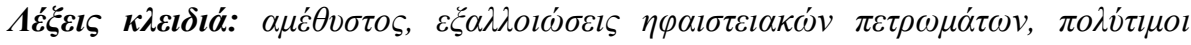
$\lambda i \theta o l$.

\section{Introduction}

Amethyst is a quartz variety often used in jewellery and occurs in varying shades of violet colors (Lieber, 1994). Its name comes from the ancient Greek words " $a$ " (not) and "methustos" (intoxicated), a reference to the belief that the stone protected its owner from drunkenness. The colors of amethyst range from light pinkish to dark mauve/blue and are due to irradiation, iron impurities (in some cases in conjunction with transition element impurities), and the presence of trace elements, which result in complex crystal lattice substitutions. Amethyst was firstly used as a gemstone by the ancient Egyptians. Later, the ancient Greeks and Romans wore amethyst and made drinking vessels of it, in the belief that it would prevent them from intoxication, while medieval European soldiers wore amethyst amulets as protection in battle believing that amethysts heal people and keep them cool-headed. Nowadays, amethysts are used very often in jewellery, in spite of its relatively low price, which came as a result of the discovery of huge amethyst deposits, mainly in South America (Brazil) and elsewhere. Brazil is the main amethyst producer today, counting more than ten very important deposits. Other amethyst producing countries are Mexico, Uruguay, South Korea, Russia, Zambia and India, but the best varieties of amethysts come from Siberia and Sri Lanka. Amethyst is also found in several other minor localities worldwide, mainly associated to volcanic rocks. Amethyst can be formed in igneous, metamorphic and sedimentary rocks as well as in hydrothermal veins, metasomatic and hot spring deposits. Well-formed crystals occur filling druses in various igneous rocks, such as granites, in gneisses or volcanic rocks, mainly lavas. In metamorphic rocks, amethyst is a quite common mineral in the so-called alpinetype fissures. Greece includes several areas with major and minor occurrences of amethyst deposits (Voudouris and Katerinopoulos, 2004; Voudouris et al., 2004; Melfos, 2005; Maneta and Voudouris, 2010). These deposits are associated with magmatic-hydrothermal (e.g. skarns, volcanic rocks) and metamorphic environments of various ages. This study focuses on five amethyst deposits which are related to the Tertiary volcanic rocks of Greece. Three amethystbearing areas are located at Northern Greece (Sapes, Kirki, Kornofolia), while the rest two occur in Lesvos and Milos islands in the Aegean Sea. Host rocks for the studied amethyst occurrences are lavas and pyroclastics of calc-alkaline to shoshonitic composition and Oligocene to Pleistocene age. This work presents results on the local geology, mineralogy and the depositional environment of the five studied amethyst deposits. 


\section{Regional Geology}

In the Aegean region, continuous subduction of both oceanic and continental lithosphere beneath the Eurasian plate since Early Cretaceous resulted to a series of magmatic arcs from the north (Rhodope massif) to the south (Active South Aegean Volcanic Arc) (Jolivet and Brun, 2010). The progressive southward migration of the magmatic centers from the Oligocene magmatic belts in the Rhodope massif, through the Miocene Aegean Islands (e.g. Limnos, Lesvos Island) to the Active South Aegean Volcanic Islands (e.g. Milos, Nisyros, Santorini) has been attributed to slab rollback following the continent-continent collision (Fytikas et al., 1984). In the Rhodope Massif, Late Cretaceous-Tertiary exhumation of metamorphic rocks along detachment faults resulted in the formation of metamorphic core complexes, post-collisional extensional collapse, and Late Eocene to Early Miocene calc-alcaline, high-K alkaline and shoshonitic magmatism (Innocenti et al., 1984; Christofides et al., 2004; Marchev et al., 2005). Geochemical data suggest that the Oligocene to Miocene plutonic rocks in Northern Greece (Rhodopes and Lesvos Island), are derived from sub-continental lithospheric mantle and/or the lower crust, with a minimal contribution from the crust (Pe-Piper and Piper, 2002). In addition, slab break-off and/or slab delamination were the principal mechanism for the generation of extensive post-collisional Oligocene magmatism in the broad Rhodope-Limnos area (Pe-Piper and Piper, 2002). On Lesvos Island, thick successions of early Miocene calc-alkaline to shoshonitic lavas and pyroclastics and basic to acid composition occupy large parts of the island (Pe-Piper and Piper, 2002). On Milos Island, calc-alkaline volcanic activity spans a period from $\sim 3.5 \mathrm{Ma}$ to the present and originated from several emergent eruptive centers characterized by both explosive and effusive activity (Fytikas et al., 1986; Stewart and McPhie, 2006; Alfieris et al., 2013). All amethyst-bearing areas are host of porphyry- and/or epithermal style of mineralization. They are characterized by intense hydrothermal alteration of the volcanic rocks, among them silicification which is closely related to the formation of amethyst-bearing quartz veins.

\section{Local Geology}

\subsection{Northeastern Greece (Sapes, Kirki and Kornofolia)}

The presence of amethyst in Sapes area has already been described by Voudouris (1993). Host rocks are hydrothermally altered lavas and pyroclastics of the Sapes stratovolcano. Amethyst occurs within colloform and crustiform banded epithermal quartz-chalcedony veins crosscutting mostly sericitic- and K-feldspar (adularia) altered volcanic rocks (Figure 1a). The amethyst veins are often accompanied by gangue adularia (Figure 2a). Amethyst-bearing veins also crosscut advanced argillic-altered volcanic rocks, resulting in an obliteration of adularia and replacement by aluni within the veins. Massive deep-violet amethyst veins occur within the "Silver Hill" formation, which is a phreatomagmatic conglomerate, probably within Maar-diatreme (Shawh and Constantinides, 2001). Amethyst in the "Silver Hill" formation, also form idiomorphic prismatic crystals (up to $3 \mathrm{~cm}$ in length), sometimes developed atop a lower part composed of smoky quartz.

In Kirki area unaltered-to-propylitized lavas of dacitic composition and Early Oligocene age are the host rocks of chalcedony-amethyst bearing veins (Figure 1b). The veins are related to NNWtrending fault zones crosscutting the dacitic rock. Open spaces within the veins are filled by up to $1 \mathrm{~cm}$ long amethyst crystals and/or milky quartz. Zeolites (analcime, heulandite, chabazite) predate (Figure $2 \mathrm{~b}$ ), whereas calcite postdates the deposition of the amethyst. Calcite has a platy habit, an indication of deposition by boiling hydrothermal fluids (according to Simmons and Browne, 2001).

Similarly to Kirki area, the amethyst in Kornofolia is hosted within unaltered to propylitized lavas of dacitic composition (Figure 1c). The quartz veins are banded with an external layer of chalcedony and inner open spaces filled by idiomorphic prismatic amethyst crystals. In some veins amethyst is missing and vugs are filled by botryoidal or stalactitic chalcedony with light pinkish 
colors. Smectite, zeolites and calcite are present as accessory minerals both within the veins and in the wall rocks (Figure 2c).

\subsection{Lesvos Island}

Amethyst in Lesvos is related to N-trending epithermal quartz veins and associated fault zones that crosscut propylitic- or sericitic altered lavas in the northern part of the Island. The veins are banded and brecciated and consist of quartz, carbonate and fluorite with minor chlorite or sericite. Idiomorphic amethyst crystals up to $10 \mathrm{~cm}$ in length mostly occur in the centers of the veins (Figure 1d). Sceptered and window amethyst (Figure 1e, f) is common and their habit (Muzo-type) resembles amethysts from Mexico (Voudouris and Katerinopoulos, 2004; Maneta and Voudouris, 2010).
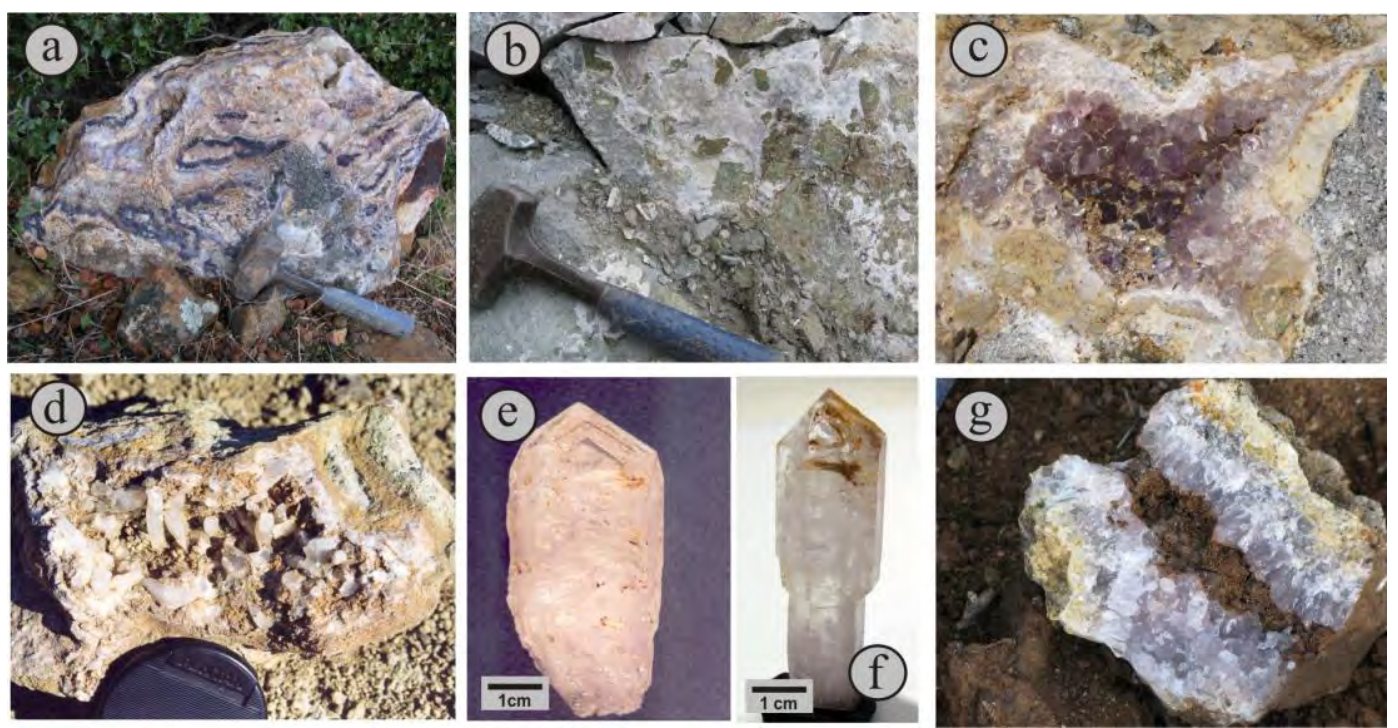

Figure 1 - Fieldphotos and hand specimens of volcanic-hosted amethyst in Greece. (a) alternations of dark violet amethyst with chalcedony from Sapes area; (b) veinlets of amethyst and calcite crosscutting propylitic lavas in Kirki area; (c) amethyst crystals overgrown on chaclcedony within a cavity of dacite, Kornofolia area (field of view $10 \mathrm{~cm}$ ); (d) amethyst crystals and calcite in a cavity of propylitic andesite lavas, Lesvos island (photo is from Voudouris and Katerinopoulos, 2004); (e,f) Scepter and window habits of prismatic amethyst from Lesvos island; (f) Short prismatic violet amethyst crystals from Milos island (field of view $10 \mathrm{~cm}$ ).

\subsection{Milos Island}

On Milos Island, amethyst is present in two localities namely the Chondo Vouno and the Vani area. In both areas amethyst is found within banded quartz-chalcedony barite veins crosscutting sericitic- and adularia altered pyroclastics (Chondro Vouno) and propylitic lavas of dacitic composition (Vani). The veins display typical epithermal features (colloform-crustiform banding) and reach thickness of up to $2 \mathrm{~m}$ and length of several tens of meters. Similarly to the Kirki and Kornofolia areas, chalcedonic quartz is deposited first in the veins and is followed by the formation of amethyst crystals in the vein centers (Figure 1g). Amethyst in Vani area is overgrown by late botryoidal aragonite. Radial aggregates of lepidocrocite included in amethyst, and related to various colourations ranging from light pink to dark violet. 


\section{Materials and Methods}

Thirty-five thin and ten thin-and-polished sections of amethyst-bearing veins and host rocks were studied respectively by optical and a JEOL JSM 5600 scanning electron microscope, equipped with back-scattered imaging capabilities, at the Department of Mineralogy and Petrology, University of Athens. The operating conditions were: accelerating voltage $20 \mathrm{kV}$, beam current 0.5 $\mathrm{nA}$, time of measurement $60 \mathrm{sec}$ and beam diameter 1-2 $\mu \mathrm{m}$. The spectra were processed using the ZAF program (3 interactions).

\section{Mineralogy and Mineral Chemistry}

A detailed mineralogical and mineral chemical study of the amethyst-bearing material revealed various mineralogical association suggestive specific conditions of crystallization. The most abundant minerals in all assemblages are quartz and chalcedony, while carbonates, barite, zeolites, chlorite, adularia, sericite, pyrite and in minor amounts halite, goethite and lepidocrocite are present (Figure 2). Electron microprobe analyses are presented in Table 1 and the data are ploted in binary and ternary diagrams (Figure 3).

\subsection{Adularia}

Adularia is a common constituent in the Sapes amethyst deposit. Along with quartz, adularia usually replaces plagioclase, clinopyroxene and amphibole of the host rock, which is a silicified dacite-andesite. Adularia forms idiomorhic rhombohedral crystals (Figure 2a), overgrowing amethyst crystals, or can be present as tiny inclusions in chalcedony and amethystine quartz. EPMA data, revealed a stoichiometric composition for the adularia from Sapes area, with some Ba up to $0.69 \mathrm{wt} \%$, corresponding to $0.01 \mathrm{apfu}$, substituting for $\mathrm{K}$ (which ranges from 0.97-1.01 apfu). A small percentage of $\mathrm{Na}_{2} \mathrm{O}(0.20-0.32$ wt \%), corresponding to 0.02 apfu, also substitutes for $\mathrm{K}$ (Table 1).

\subsection{Zeolites}

Zeolites are significant accessory minerals in both Kornofolia and Kirki amethyst deposits. Clinoptilolite-Ca and heulandite-Ba (Kornofolia) and analcime (Kirki) usually form euhedral crystals that fill both quartz- and carbonate-rich veins. Deposition in the Kirki veins starts with alternations between analcime and calcite layers, followed by chalcedony and finally by amethyst, which forms short prismatic crystals in the center of the veins (Figure 2b). In the Kornofolia locality a chalcedony layer overgrowths zeolitized wallrocks, and is succeeded by deposition of amethyst, and then by clinoptilolite-Ca and finally calcite (Figure 2c). Heulandite-Ba (Coombs et al., 1998; Larsen et al., 2005) forms euhedral crystals present as inclusions in clinoptilolite-Ca. Electron microprobe analyses revealed that clinoptilolite has an almost stoichiometric composition, with relatively elevated contents of $\mathrm{Ca}$ and $\mathrm{K}$ corresponding up to 2.16 and 1.35 apfu respectively. The analyzed heulandites revealed variable cation contents with $\mathrm{K}$ (up to $2.7 \mathrm{apfu}$ ) substituting for $\mathrm{Na}$ and relatively high $\mathrm{Ba}$ contents ( $\mathrm{BaO}$ up to 15.97 wt. \%), corresponding up to 3.24 apfu. Chemical analyses of analcime from both Kirki and Kornofolia amethyst deposits, revealed stoichiometric compositions, with a stable $(\mathrm{K}+\mathrm{Na}) /(\mathrm{K}+\mathrm{Na}+\mathrm{Ca})$ ratio close to 1 , whereas the $\mathrm{Si} / \mathrm{Al}$ ratio shows a small variance between 2-2.4 (Figure 3a,b).

\subsection{Chlorite}

Chlorite is a common alteration mineral of the volcanic rocks hosting amethyst-bearing veins at Lesvos island. In this locality the propylitic altered lavas contain pyroxene and hornblende phenocrysts pseudomorph after chlorite, calcite and sericite. The later minerals also occur within the amethyst veins. Electron microprobe analyses of chlorite are presented in Table 1 and the data are ploted in terms of $\mathrm{Fe}_{\text {tot }}$ vs $\mathrm{Si}$ (Figure 3d). The Lesvos chlorites are classified as pycnoclorites and diabantites (Figure 3d). 


\subsection{Sericite}

Sericite together with chlorite replaces plagioclase, amphibole and clinopyroxene of the propylitic andesites, in the Lesvos amethyst deposit. It is also present as part of the sericitic alteration zones surrounding amethyst-bearing veins in Sapes area. Electron microprobe analyses revealed minor amounts of $\mathrm{Mg}, \mathrm{Fe}, \mathrm{Na}, \mathrm{Ca}, \mathrm{Sr}$ and $\mathrm{Ti}$ in the structural formula (Table 1).
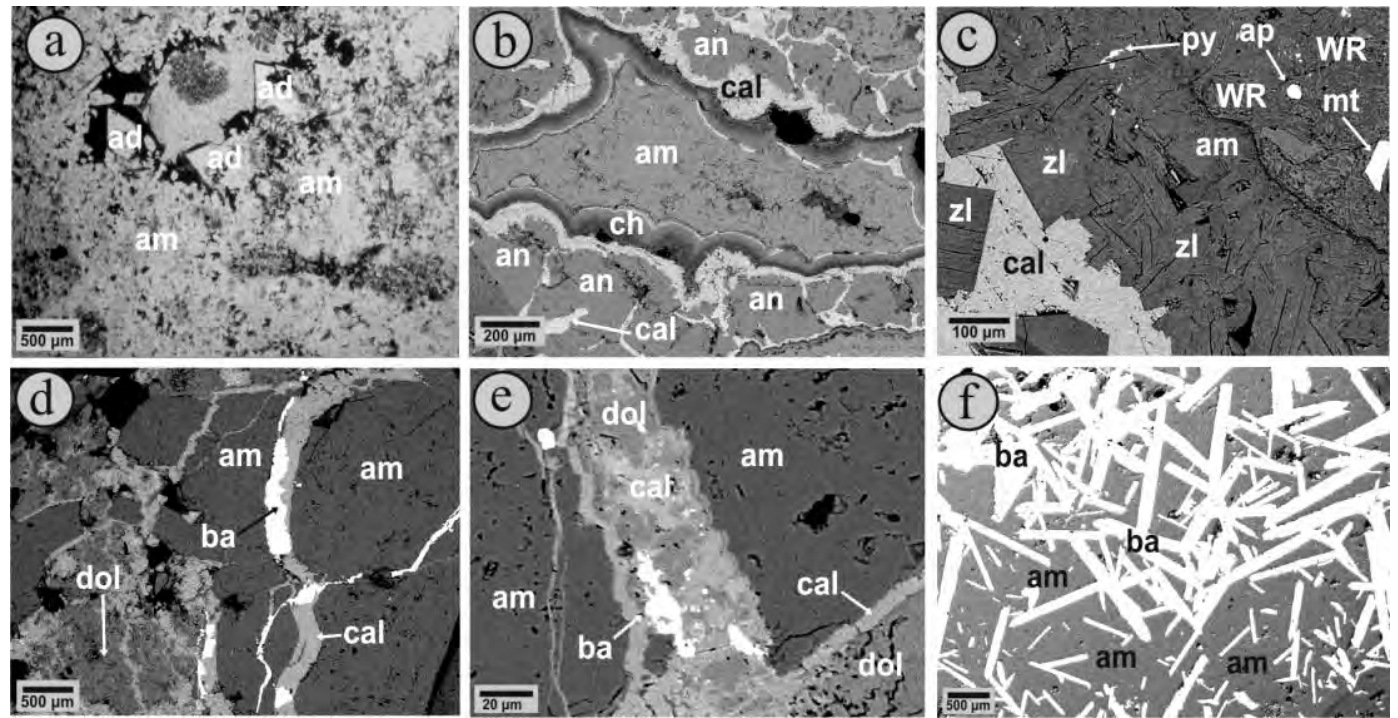

Figure 2 - Microphotographs demonstrating mineralogical assemblages of amethyst-bearing veins (a) adularia (ad) in association with amethyst (am) from Sapes area (reflected light, plane polarized); (b) cavity filled with analcime (an), then calcite (cal), which is rimmed by chalcedony (ch) with final deposition of amethyst (am), Kirki area (SEM-BSE image); (c) clinoptilolite-Ca (zl) and calcite (cal) that overgrow amethystine quartz (am) are filling cavities of dacitic lavas characterized by plagioclase (pl) and disseminated crystals of apatite (ap) and magnetite (mt), Kornofolia area (SEM-BSE image); (d,e) amethyst (am) is rimmed or crosscut by calcite (cal), dolomite (dol) and barite (bar), Lesvos island (SEM-BSE images);

(i) intergrowth of barite (bar) and amethyst (am) at Milos island (SEM-BSE image) .

\subsection{Calcite - Dolomite}

Carbonate minerals, mainly calcite and less commonly dolomite-calcite solid solution, accompany amethyst at Kirki, Kornofolia and Lesvos Island (Figure 3c). Dolomite is absent at Kirki, Kornofolia and the amethyst pre- and/or postdates calcite in vein cavities (Figure 2b, c). In Lesvos Island, amethyst crystals are overgrown and crosscut by calcite-dolomite solid solution and calcite. Initial deposition of calcite-dolomite solid solution was followed by deposition of calcite and barite (Figure $2 \mathrm{~d}, \mathrm{e}$ ). Electron microprobe analyses indicated up to $18.6 \mathrm{wt}$ \% $\mathrm{MgO}$ and $4.6 \mathrm{wt}$. \% FeO substituting for $\mathrm{Ca}$. Minor amounts of $\mathrm{Mn}(\mathrm{MnO}$ up to $1.05 \mathrm{wt} \%$ ) and $\mathrm{Sr}(\mathrm{SrO}$ up to $0.28 \mathrm{wt} \%$ ), are detected in calcite from Lesvos.

\subsection{Barite}

Barite is very abundant in Milos amethyst deposits and also occurs in minor amounts in the Sapes and Lesvos occurrences. The Milos amethyst is accompanied by idiomorphic barite crystal reaching sizes of up to $10 \mathrm{~cm}$ in length. Barite can also be found as inclusions in amethyst and chalcedony (Figure 2f), or postdates amethyst deposition. Its chemical composition is close to stoichiometry, with minor amounts of $\mathrm{SrO}$ (up to $3.41 \mathrm{wt} \%$ ), substituting for $\mathrm{Ba}$ in the structure. 


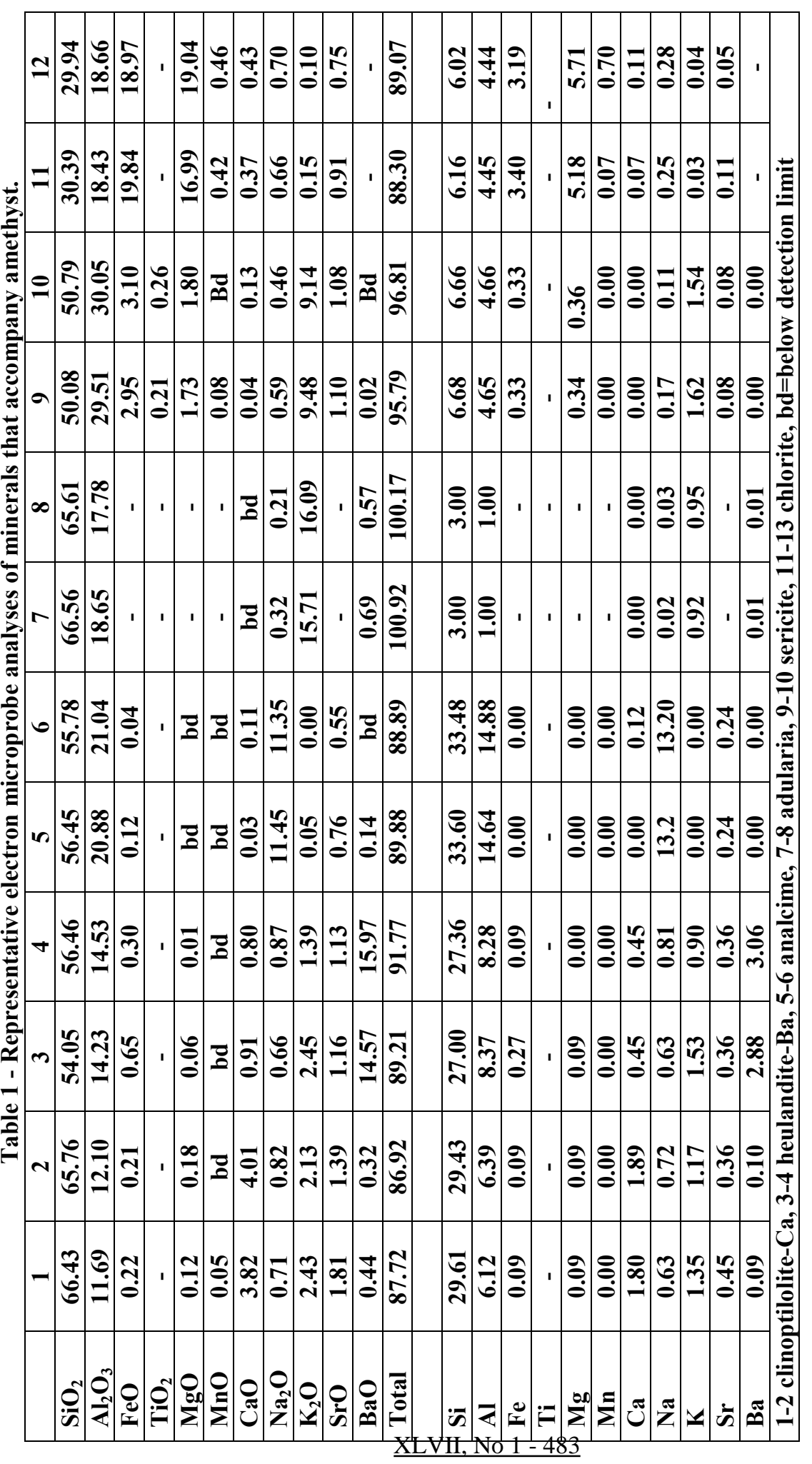




\section{Discussion and Conclusions}

Amethyst can be formed in a great variety of geological environments. In Greece, amethyst has been found in well-formed crystals within extensional alpinotype fissures in metamorphic core complexes, which are related to tectonic exhumation of the Rhodope- and Attico-Cycladic massifs (Voudouris et al., 2004). Excellent amethyst crystals are also found in the skarn of Serifos Island, where amethyst occur as sceptre on prase quartz crystals. However the above occurrences are of minor compared to the volcanic-rock hosted occurrences described in this study, which can be also considered as potential deposits for possible future exploitation.

The volcanic-hosted amethyst deposits described in the present study, are genetically related to the development of epithermal systems, during the waning stages of Oligocene to Pleistocene volcanic activity. In all studied occurrences the amethyst occurs distally, and is probably genetically related to the evolution of major $\mathrm{Cu}-\mathrm{Mo}$ porphyry and associated high-sulfidation epithermal mineralization (Voudouris and Katerinopoulos, 2004). Mineralogical and geological information indicates that amethyst formation is late in respect to the above mineralization, and took place mainly from near neutral-pH to alkaline fluids and in the stability field of adularia, calcite and zeolites. The presence of sericite in some amethyst veins at Sapes, suggest slighty acid conditions during amethyst formation. All the studied amethyst occurrences are related to intermediate- to low-sulfidation epithermal veins with a well developed hydrothermal alteration zoning (e.g. silicic alteration grading outward to adularia and/or sericitic alteration, then to argillic-, propylitic-, zeolitic alteration and finally to fresh volcanic rock). Amethyst occurs in quartz veins crosscutting all the above alteration zones.

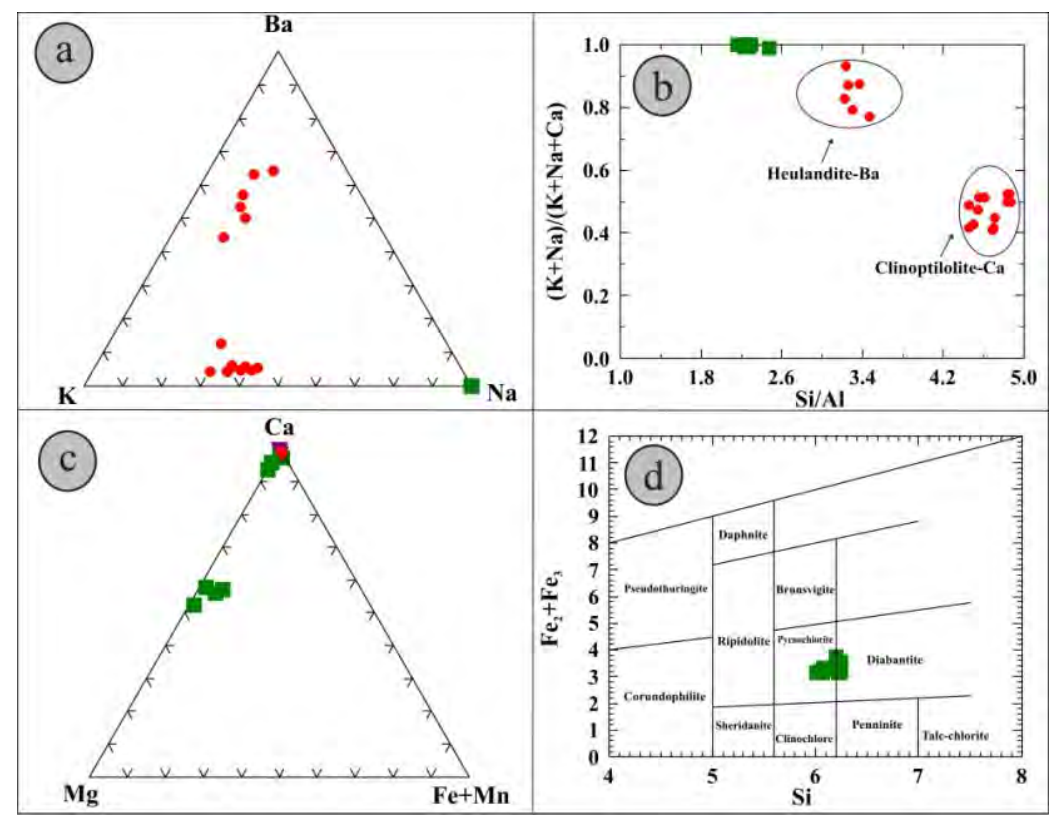

Figure 3 - (a) ternary Ba-K-Na plot of zeolites; (b) binary plot $[(\mathrm{K}+\mathrm{Na}) /(\mathrm{Ca}+\mathrm{Na}+\mathrm{K})]$ versus (Si/Al) of zeolites (squares = analcime from Kirki area and circles = zeolites from Kornofolia area); (c) ternary Ca-Mg-Mn plot for calcites and dolomites from Kirki (triangles), Kornofolia (circles) and Lesvos island (squares); (d) binary $\mathrm{Fe}_{\text {total-Si classification diagram of chlo- }}$ rites from Lesvos amethyst deposit (after Hey, 1954).

The mineralogical data presented in this study as well as published fluid inclusion data were used to estimate the crystallizing conditions of the studied amethyst: In Kirki area the coexistence of laumontite, analcime, heulandite and smectite suggests maximum temperatures of $175^{\circ} \mathrm{C}$. Similar 
temperatures of formation can be assumed through the coexistence of heulandite and clinoptilolite, accompanying amethyst in Kornofolia area. Temperatures in the range from $100-175^{\circ} \mathrm{C}$ are compatible with the presence of chalcedony in the studied occurrences (Fournier, 1985). Application of the chlorite geothermometer after Cathelineau (1988) suggested temperatures of amethyst formation in the range $223-234{ }^{\circ} \mathrm{C}$. The Lesvos amethyst is intergrown with calcitedolomite, barite (and locally fluorite and epidote) suggesting deposition from near neutral $\mathrm{pH}$ and $\mathrm{SO}_{4}{ }^{2-}$ and $\mathrm{F}^{-}$bearing solutions. In Milos island, fluid inclusion data from the Vani and Chondro Vouno occurrences by Kilias et al. $(2001,2007)$ and Naden et al. (2005) demonstrate temperatures in the range from about $100^{\circ}$ to $230^{\circ} \mathrm{C}$, boiling conditions, and involvement of seawater in addition to meteoric water for the amethyst deposition. A significant contribution of seawater during amethyst formation is also indicated by the presence of halite inclusion in the zeolites from the studied Kirki and Kornofolia occurrences. Fluid inclusion data for Sapes amethyst indicate homogenization temperatures in the range from 174 to $289^{\circ} \mathrm{C}$ and salinities from 0.5 to $3.5 \mathrm{wt}$. \% NaCl equiv. demonstrating probable contribution of meteoric waters in their formation (Voudouris, 1993; Melfos, 2005). It is suggested that amethyst requires oxidizing conditions to obtain its colour, and this may be resulted by either mixing of oxidized meteoric and/or seawaters with upwelling hydrothermal fluids or boiling processes (Fournier, 1985). Both processes are considered to have caused amethyst formation in the studied areas as indicated by the mineralogical and existing fluid inclusion data. Boiling processes are responsible for the crystallization of amethyst together with adularia at Sapes and platy calcite at Kirki areas (according to Simmons and Browne, 2001). Shallow submarine conditions are most likely to have prevailed in all areas, Sapes being probably under subaerial conditions. The volcanic-hosted amethysts in Greece are of gemstone quality. Ongoing geological and gemmological work aims to evaluate their potential for future explotation.

\section{Acknowledgments}

Prof. Dr. Georgia Pe-Piper and Prof. Dr. E. Manoutsoglou are greatly acknowledged for their helpful and constructive comments, which improved the initial manuscript.

\section{References}

Alfieris D., Voudouris P. and Spry P.G. 2013. Shallow submarine epithermal Pb-Zn-Cu-Au-Ag-Te mineralization on western Milos Island, Aegean Volcanic Arc, Greece: Mineralogical, Geological and Geochemical constraints, Ore Geol. Rev., 53, 159-180.

Cathelineau M. 1988. Cation size occupancy in chlorites and illites as a function of temperature, Clay Minerals, 23, 471-485.

Christofides G., Soldatos T., Eleftheriadis G. and Koroneos A. 1998. Chemical and isotopic evidence for source contamination and crustal assimilation in the Hellenic Rhodope plutonic rocks, Acta Vulcanol., 10, 305-318.

Christofides G., Pecskay Z., Soldatos T., Eleftheriadis G. and Koroneos A. 2004. The Tertiary Evros volcanic rocks (Greece): Petrology, $\mathrm{K} / \mathrm{Ar}$ geochronology and volcanism evolution. Geol. Carp., 55, 397-409.

Coombs D.S., Alberti A., Armbruster T., Artioli G., Colella C., Galli E., Grice J.D., Liebau F., Mandarino J.A., Minato H., Nickel E.H., Passaglia E., Peacor D.R., Quartieri S., Rinaldi R., Ross M., Sheppard R.A., Tillmanns E. and Vezzalini G. 1998. Recommended nomenclature for zeolite minerals: Report of the Subcommittee on Zeolites of the Mineralogical Association, Commision on New Minerals and Mineral Names, Eur. J. Mineral., 10, 1037-1081.

Fournier R.O. 1985. The behaviour of silica in hydrothermal solutions. In Berger, B.R., and Bethke, P.M., eds., Geology and geochemistry of epithermal systems, Rev. Econ. Geol., 2, 45-61.

Fytikas M., Innocenti F., Manneti P., Mazzuoli R., Peccerillo A. and Villari L. 1984. Tertiary to Quaternary evolution of volcanism in the Aegean region, in Dixon, J.E., and Robertson, 
A.H.F., eds., The geological evolution of the eastern Mediterranean, Geol. Soc. Spec. Publ., 17, 687-699.

Fytikas M., Innocenti F., Kolios N., Manneti P., Mazzuoli R., Poli G., Rita F. and Villari L. 1986. Volcanology and petrology of volcanic products from the island of Milos and neighbouring islets, J. Volcanol. Geotherm. Res., 28, 297-317.

Hey M.H. 1954. A new review of the chlorites, Mineral. Mag., 30, 277-292.

Innocenti F., Kolios N., Manetti O., Mazzuoli R., Peccerillo G., Rita F. and Villari L. 1984. Evolution and geodynamic significance of the Tertiary orogenic volcanism in northeastern Greece, Bull. Volcanol., 47, 25-37.

Jolivet L. and Brun J.P. 2010. Cenozoic geodynamic evolution of the Aegean region, Int. J. Earth. Sci., 99, 109-138.

Kilias S.P., Naden J., Cheliotis I., Shepherd T.J., Constandinidou H., Crossing J. and Simos I. 2001. Epithermal gold mineralisation in the active Aegean volcanic arc: the Profitis Ilias deposit, Milos island, Greece, Mineral. Deposita, 36, 32-44.

Kilias S.P., Detsi K., Godelitsas A., Typas M., Naden J. and Marantos Y. 2007. Evidence of Mnoxide biomineralization, Vani Mn deposit, Milos, Greece, Proc. of the ninth Biennial SGA Meeting, Dublin, 1069-1072.

Larsen A.O., Nordrum F.S., Döbelin N., Armbruster T., Petersen O.V. and Erambert M. 2005. Heulandite-Ba, a new zeolite species from Norway, Eur. J. Mineral., 17, 143-153.

Lieber W. 1994. Amethyst: Geschichte, Eigenschaften, Fundorte, Christian Weise Verlag, München, $188 \mathrm{pp}$.

Maneta V. and Voudouris P. 2010. Quartz megacrysts in Greece: Mineralogy and environment of formation, Bull. Geol. Soc. Greece, XLIII, 685-696.

Marchev P., Kaiser-Rohrmeier M., Heinrich Ch., Ovtcharova M., von Quadt A. and Raicheva R. 2005. Hydrothermal ore deposits related to post-orogenic extentional magmatism and core complex formation: the Rhodope Massif of Bulgaria and Greece, Ore Geol. Rev., 27, 53-89.

Melfos V. 2005. Study of fluid inclusions in amethysts from areas of Macedonia and Thrace: Sapes, Soufli, Nevrokopi, $2^{\text {nd }}$ Congress of the Economic Geology Committee, Mineralogy \& Petrology (GSG), Thessaloniki, October 2005, 219-228. (in Greek)

Naden J., Kilias S.P. and Darbyshire D.B.F. 2005. Active geothermal systems with entrained seawater as analogues for transitional continental magmato-hydrothermal and volcanic-hosted massive sulfide mineralization: the example of Milos Island, Greece, Geology, 33, 541-544.

Pe-Piper G. and Piper D.J.W. 2002. The Igneous rocks of Greece - The anatomy of an orogeny, Gebruder Borntraeger, 30, 573 pp.

Rykart R. 1995. Quarz-Monographie, Ott Verlag Thun, 461 pp.

Shawh A.J., and Constantinides D.C. 2001. The Sappes gold project, Bull. Geol. Soc. Greece. 34, 1073-1080.

Simmons S.F. and Browne P.R.L. 2001. Hydrothermal minerals and precious metals in the Broadlands-Ohaaki geothermal system: implications for understanding low-sulfidation epithermal environments, Econ. Geol., 95, 971-999.

Stewart A.L. and McPhie J. 2006. Facies architecture and Late Pliocene-Pleistocene evolution of a felsic volcanic island, Milos, Greece, Bull. Volcanol., 68, 703-726.

Voudouris P. 1993. Mineralogical, geochemical and fluid inclusion studies on epithermal vein type gold-silver mineralizations at Kassiteres/Sapes, (NE- Greece). PhD Thesis, Univ. Hamburg, 218 pp (in German).

Voudouris P. and Katerinopoulos A. 2004. New occurences of mineral megacrysts in Tertiary magmatic-hydrothermal and epithermal environments in Greece, Documenta Naturae, 151, $1-21$.

Voudouris P., Katerinopoulos A. and Melfos V. 2004. Alpine-type fissure minerals in Greece, Documenta Naturae 151, 23-45. 